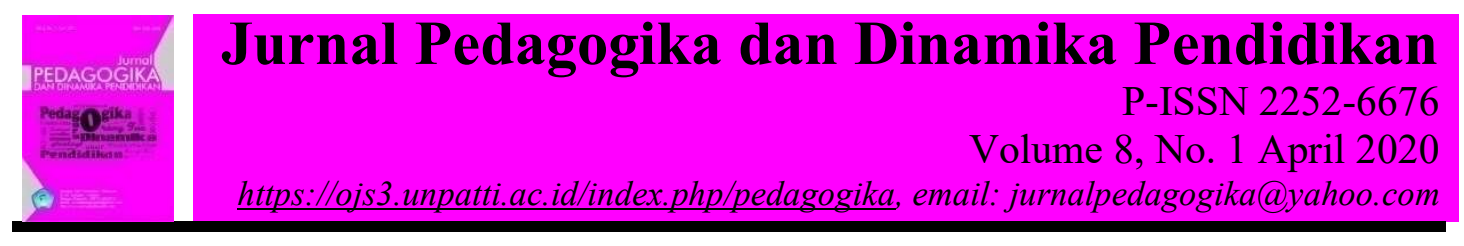

\title{
ISLAM DI TENGAH PLURALITAS DAN KEMANUSIAAN DALAM MEMBANGUN SOLIDARITAS DAN TOLERANSI
}

\author{
Erwin Notanbun \\ Dosen Program Studi PGSD FKIP Univeritas Pattimura Ambon \\ Email. ifaaleza@gmail.com
}

\begin{tabular}{|c|c|}
\hline ARTICLE INFO & ABSTRACT \\
\hline $\begin{array}{l}\text { Article History: } \\
\text { Accepted } 27 \text { Maret } 2020 \\
\text { Available Online } 20 \text { April } 2020\end{array}$ & $\begin{array}{l}\text { Pada hakikatnya posisi manusia terhadap } \\
\text { sesamanya adalah sama dan sederajat, sama-sama } \\
\text { sebagai ciptaan (makhluq) Allah SWT, dan } \\
\text { karenanya di hadapan Allah SWT semuanya } \\
\text { sama, yang membedakannya hanyalah amal } \\
\text { perbuatannya atau ketakwaannya saja. Oleh } \\
\text { karena itu, secara individual hubungan manusia } \\
\text { dengan manusia lainnya, masing-masing }\end{array}$ \\
\hline $\begin{array}{l}\text { Keywords: } \\
\text { Islam, Pluralisme, Solidaritas, } \\
\text { dan Tolerasi }\end{array}$ & $\begin{array}{l}\text { mempunyai kekuasaan yang sama, setiap } \\
\text { individu dengan individu lainnya tidak boleh } \\
\text { saling memaksa apalagi merampas hal-haknya. } \\
\text { Hak individu untuk mempertahankan miliknya } \\
\text { dilindungi oleh hukum apapun, karena hal itu } \\
\text { adalah bagian dari hak asasi manusia yang wajib } \\
\text { dilindungi. Islam datang tidak hanya bertujuan } \\
\text { mempertahankan eksistensinya sebagai agama, } \\
\text { tetapi juga mengakui eksistensi agama-agama } \\
\text { lain, dan memberinya hak untuk hidup } \\
\text { berdampingan sambil menghormati pemeluk- } \\
\text { pemeluk agama lain. }\end{array}$ \\
\hline
\end{tabular}

\section{A. PENDAHULUAN}

Moderasi adalah keseimbangan antara eksistensi dan toleransi. Maka eksistensi Islam harus ditegakkan dan sebaliknya tidak boleh dirugikan oleh toleransi. Akan tetapi toleransi itu pun harus diberi porsi proposional pada eksistensi itu sendiri. Toleransi yang merugikan eksistensi maka akan menjadi toleransi kebablasan, sementara eksistensi tanpa toleransi maka akan menjurus pada ekstremisme. 
Eksistensi Islam atau Islam natural, yang sudah diterapkan secara azali oleh Allah SWT adalah memiliki karakter toleran, sehingga ia menjadi rahmatan lil'alamin, bukan hanya rahmatan lil muslimin. Hanya saja memang implementasinya dilapangan tidaklah mudah.

Faktanya, jangankan Islam untuk menjadi rahmatan lil 'alamin, di antara ummat Islam sendiri yang terjadi adalah keberadaannya menjadi fitnatan lilmuslimin, fitnah bagi sesama muslim sendiri. Hal ini terjadi karena kita abai akan perintah menjaga ukhuwah 'persaudaraan' di antara kita.

Demikian pula hubungan kita dengan ummat yang lain. Bukankah di dalam piagam Madinah telah digariskan oleh Rosulullah, bahwa ummat Islam Yahudi, dan Nasrani boleh hidup di Madinah bersama-sama. Batasannya adalah di dalam perkara agama lakum dinukum waliyadin. Bagimu agamamu, bagiku agamaku. Tetapi dalam hal lain, hak perlindungan, pendidikan, kesehatan, dan lainnya memiliki hak yang sama. Jadi pluralism disini adalah pluralism ideology, sama sekali bukan pluralism teologi.

Inilah yang menjadi batasannya. Namun, tak bisa disangkal bahwa ada sebagian dari kita yang kemudian keluar dari batas itu. Kadang-kadang orang karena ingin moderat sekali kebablasan dalam memberikan toleransi. Misalnya ia menerima pluralisme teologis, sehingga mencampuradukkan ibadah di dalam hubungan sosial. Hal yang demikian tentu terlalu ingin eksis sekali sehingga menolak pluralism ideology. Akhirnya paham-paham yang berbeda ditolak, bahkan diharamkan atau di kafirkan.

\section{B. METODE}

Penelitian ini penulis menggunakan metode Library "Studi Kepustakaan" yang kemudian data tersebut dianalisis secara deksriptif kualitatif. Artinya data yang dikumpulkan dari studi kepustakaan di analisis dan diseskripsikan. ${ }^{1}$

Adapun jenis dari penelitian ini merupakan jenis penelitian kualitatif (Qualitative Research), yakni penelitian yang menghasilkan penemuan yang tidak dapat dicapai dengan menggunakan prosedur statistik atau cara lain kauantifikasi (pengkuran). ${ }^{2}$ Jadi penelitian ini merupakan penelitian kualitatif tentang model penafsiran para pakar terkait dengan masalah toleransi.

\footnotetext{
${ }^{1}$ Ronny Kountur, Metode Penelitian untuk Penulisan Skripsi dan Tesis. (Jakarta: PPM, 2005). Hal. 105

${ }^{2}$ Sutrisno Hadi, Metodologi Research (Yogyakarta: Andi Ofset, 1990). Hal. 139
} 


\section{PEMBEHASAN Mengelola Perbedaan}

Banyak benda sehari-hari di lingkungan kita yang sebetulnya bermata dua. Beberapa yang dapat disebutkan adalah api, pisau, air, bahkan yang tergolong jenis obat-obatan di mana jika digunakan secara baik mendatangkan kebaikan namun jika penggunaannya tidak tepat justru membahayakan. Demikian pula yang terjadi pada sebuah kondisi masyarakat yang heterogen yang dapat dipastikan kaya dengan perbedaan, baik dalam zona makro antar kelompok dalam masyarakat. Dari sisi kedalaman perbedaan, dapat berbeda gaya bicara sampai dengan berbeda keyakinan dan aliran dalam suatu keyakinan. Perbedaan-perbedaan tersebut dapat beranalogi dengan api, pisau, dan air yang tidak dapat dipungkiri bermata dua dimana dapat ditempatkan sebagai anugerah di satu sisi dan dapat menjadi bencana pada sisi lainnya. Kedewasaan sikap, mental, cara berpikir, dan tingkat peradaban yang dapat memberikan arah kemana akan dibawa ke kebaikan atau kebencanaan.

Dalam realitanya, perbedaan merupakan sebuah keniscayaan, sebuah anugerah Ilahi yang wajib disyukuri dan disikapi dengan baik oleh semua agama. Makin besar sebuah komunitas dapat menerima perbedaan sering kali berkorelasi dengan semakin majunya peradaban dan semakin tingginya pemahaman nilai-nilai universal di mana Islam syarat dengan ajaran-ajaran universal tersebut. ${ }^{3}$

Pada hakikatnya posisi manusia terhadap sesamanya adalah sama dan sederajat, sama-sama sebagai ciptaan (makhluq) Allah, dan karenanya di hadapan Allah semuanya sama, yang membedakannya hanyalah amal perbuatannya atau ketakwaannya saja. Oleh karena itu, secara individual hubungan manusia dengan manusia lainnya, masing-masing mempunyai kekuasaan yang sama, setiap individu dengan individu lainnya tidak boleh saling memaksa apalagi merampas hal-haknya. Hak individu untuk mempertahankan miliknya dilindungi oleh hukum apapun, karena hal itu adalah bagian dari hak asasi manusia yang wajib dilindungi. ${ }^{4}$

Sebuah pertanyaan yang jawabannya sudah ada dan permanen, yaitu bahwa Tuhan menciptakan makhluk-Nya beserta perbedaannya. Bahwa Tuhan menciptakan makhluk-Nya menjadi berbeda-beda baik sebagai individu maupun kelompok merupakan kenyataan klasik normative yang tidak terbantahkan selamanya. Namun, seringkali kenyataan tersebut ingin dikalahkan oleh keegoan kelompok atau individu oleh mereka yang justru mengangap diri sebagai pemeluk agama yang taat. Justru mereka yang mengatasnamakan pemeluk agama yang taat sering menolak kenyataan dan sebaliknya beranggapan bahwa hanya diri dan kelompoknya yang paling betul di hadapan Tuhan. Berhadapan dengan kondisi tersebut, diperlukan kejernihan berpikir dan penguatan diri baik secara individu maupun kelompok bahwa toleransi merupakan jalan yang diamanatkan dalam Islam. Kekuatan toleransi terdapat pada optimisme kedamaian di mana pun individu dan kelompok berada. Sebaliknya,

\footnotetext{
${ }^{3}$ Alwi Shihab, Islam dan Kebinakaan, Jakarta: PT Gramedia Pustaka Uatama, 2019. Hal 2

${ }^{4}$ Musa Asy’Arie, Filsafat Islam, Sunnah Nabi Dalam Berpikir, Yogyakarta: LESFI, 2002 Hal. 120
} 
absennya toleransi dalam kehidupan menandakan kebangrutan kedamaian dan memicu kekonflikan. ${ }^{5}$

Perbedaan hak dan kewajiban seorang individu dalam kehidupan sosial, lebih disebabkan karena perbedaan tugas dan pekerjaan atau profesinya, sehingga hal dan kewajiban seorang dokter tertentu misalnya berbeda dengan hak dan kewajiban pasiennya, demikian juga halnya guru dan murid, orang tua dan anak. Perbedaanperbedaan itu sifatnya fungsional dan profesiaonal, tidak peduli dan tidak mutlak, artinya akan berubah dengan adanya fungsi atau terjadinya alih profesi.

Dalam kaitan ini, kebebasan seseorang dibatasi oleh kebebasan orang lain, huriyyatuka mahdudatun bihurriyyati siwaka, dan etika untuk saling menghargai dan menghormati hak-hak orang lain menjadi dasar dan landasan bagi berlangsungnya huungan dan komunikasi sosial yang sehat, dimana tidak ada paksaan dan diskriminasi berdasarkan kemestian-kemestian hidup yang menjadi bawaan kodrati, seperti ras, suku, agama dan pandangan hidup seseorang. ${ }^{6}$

Oleh karena itu, tidak ada paksaan dalam agama, masing-masing agama punya hak untuk hidup dan masing-masing pemeluk agama, seharusnya memaklumi perbedan agamnya masing-masing. Alqur'an 2:256 mengatakan:

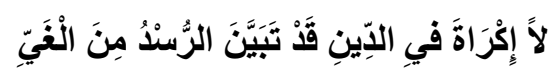

Artinya: Tidak ada paksaan dalam agama, karena sesungguhnya telah jelas jalan jalan yang benar dan jalan yang salah. Pada tempat lain, Al-Qur'an 109:4-6 mengatakan:

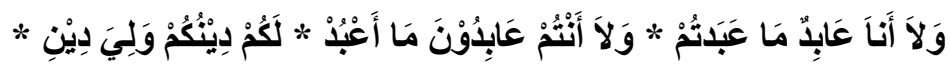

Artinya: Dan aku tidak akan menyembah apa yang kamu sembah, dan kamu tidak akan menyembah Dia yang aku sembah, untuk kamu agama kamu dan untuk aku agamaku.

Pada hakikatnya iman itu tidak bisa dipaksakan, setiap orang mempunyai jalan imannya sendiri-sendiri, iman itu sendiri tidak sama, dan iman dalam diri seseorang bisa bertambah bisa juga berkurang. Jika Tuhan menghendaki manusia semuanya beriman (dalam satu versi iman) tentu mudah, tetapi kenyataannya lain, dan karenanya beriman atau tidaknya seseorang adalah urusan Tuhan, bukan urusan manusia. Al-Qur'an mengatakan:

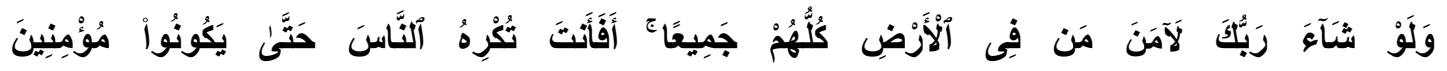

Artinnya: Kalau Tuhan mau, niscaya orang-orang yang dibumi ini akan beriman semuanya. Apakah engkau memaksa manusia suapaya mereka menjadi orang-orang yang beriman?

\footnotetext{
${ }^{5}$ Alwi Shihab, Islam dan Kebinakaan, Jakarta: PT Gramedia Pustaka Uatama, 2019. hal 3

${ }^{6}$ Musa Asy’arie, Filsafat Islam: Sunnah Nabi dalam Berpikir, YogyakartaL LESFI, 2002), hal. 122
} 
Disamping menghargai adanya perbedaan suku, ras dan agama, etika agama juga melarang masing-masing, baik individu maupun kelompok untuk menghina dan merendahkan satu dengan lainnya, karena pada dasarnya darah dan daging yang cenderung mudah tergelincir pada dorngan-dorongan tubuhnya, manusia bukan malaikat dan juga buka setan (syaitan), manusia di dalamnya ada dorongandorongan baik dan buruk, tinggal bagaimana kepemimpinan ruh di dalam dirinya.

\section{Aspek Hubungan Sosial}

Dalam bidang sosial, Islam menetapkan bahwa setiap orang bebas melakukan kegiatan sesuai dengan tuntunan agama dan kepercayaannya sambil menghormati kepercayaan para penganut agama lain.

Sejak masa Nabi Muhammad SAW. di Madinah, seluruh lapisan masyarakat dengan aneka suku dan agama di bawah pimpinan beliau setelah sepakat merumuskan apa yang kemudian di kenal dengan Piagam Madinah. Melalui piagam itu, semua bersedia membela kota Madinah dari serangan musuh, sebagaimana semua dituntut untuk lebur dalam satu masyarakat Madani yang di dalamnya semua memilki hak dan kewajiban yang sama sebagai warga. Semua sama dalam hak memperoleh pembelaan atas hak-hak mereka; demikian juga keadilan tanpa perbedaan, suku, agama, dan kedudukan sosial.

Dalam pandangan Islam semua bersaudara kendati berbeda suku atau agama. Kendati kaum 'Ad, Tsamud, dan Madyan membangkang rasul-rasul mereka, tetap saja Al-Qur'an menamai para rasul yang diutus kepada mereka itu sebagai saudarasaudara mereka, yakni Saudara sekemanusiaan. Karena itu, sungguh tepat rumus yang dikemukakan Sayyidina Ali r.a: "Siapa yang Anda temui maka dia adalah saudara Anda seagama atau saudara Anda sekemanusiaan.

Dalam konteks persaudaraan seagama, maka kalau dapat didahulukanlah saudara Anda seagama atas diri Anda. Kalau itu sulit Anda lakukan, maka perlakukanlah dia sebagaimana Anda ingin diperlakukan. Jadikanlah diri Anda neraca untuk menimbang bagaimana sebaiknya Anda memperlakukan saudara Anda! Dalam konteks ini, Nabi saw mengingatkan kita,

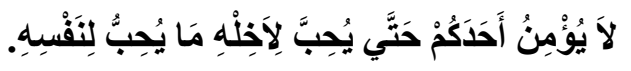

Tidak semprna iman seseorang di antara kamu sampai dia mencintai/menyukai untuk saudaranya apa yang dia sukai untuk dirinya. (HR. Bukhari dan Muslim).

Dalam satu hadis Nabi yang diriwayatkan oleh Imam Muslim yang intinya mengatakan bahwa kita jangan saling iri hati, jangan saling menjual atas jualan saudara, maksudnya, jangan menawarkan sesuatu dengan harga tinggi agar didengar oleh seorang pembeli bukan untuk tujuan menjualnya, melainkan supaya calon 
pembeli akan membeli barang yang ditawarkan oleh temannya dengan asumsi bahwa harga yang ditawarkan oleh temannya itu lebih murah. Karena ini adalah merupakan kebohongan dengan menipu si pembeli demi kemaslahatan orang lain yang merupakan temanya sendiri. Jadilah hamba-hamba Allah yang bersaudara. Seorang muslim adalah saudara bagi muslim lainnya. Dia tidak menganiaya dan tidak pula menyampaikan kepada muslim lainnya berita bohong, tidak menganiaya dan tidak pula meninggalkanya tanpa menawarkan bantuan, yakni ketika saudaranya membutuhkan bantuan. ${ }^{7}$

Terhadap non muslim, mereka harus kita perlakukan sebagai saudara sekemanusiaan. Sebagaimana pesan Islam yang dirumuskan oleh Sayyidina Ali K.W. Apa yang dirumuskan demikian menggambarkan pandangan Islam tentang hubungan antarmanusia seluruhnya tanpa perbedaan jenis, suku, atau agama dan mereka semua berasal dari satu keturunan. Tidak ada perbedaan antara mereka dari segi kemanusiaan, karena itu tidak wajar ada istilah "pihak lain” karena semua sama dari segi pandangan kemanusiaan. Yang ada adalah "kita" bukan "kami".

Apa yang dikemukakan di atas pada hakikanya bersumber dari Al-Qur'an dan Sunnah Nabi s.a.w. Kedua macam hubungan yang disebut di atas tidak boleh dipertentangkan karena "hubungan keagamaan" tidak membatalkan "hubungan kemanusiaan".

Al-Qur'an menegaskan:

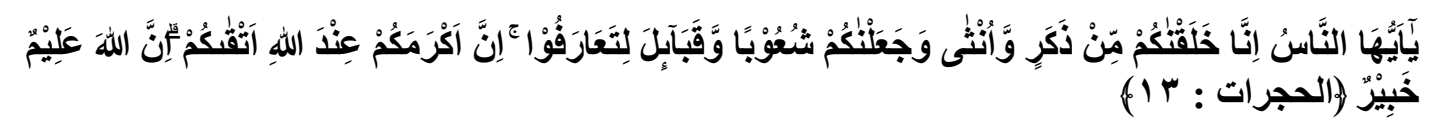

Hai manusia, sesungguhnya Kami menciptakan kamu dari seorang laki-laki dan seorang perempuan dan menjadikan kamu berbangsa-bangsa dan bersuku-suku supaya kamu saling mengenal. Sesungguhnya yang paling mulia di antara kamu di sisi Allah ialah yang paling bertakwa di antara kamu. Sesungguhnya Allah Maha Mengetahui lagi Maha Mengenal.

(Q.S.Al-Hujurat,49:13).

"Saling mengenal" adalah tujuan perantara, sedang tujuan akhirnya adalah saling membantu dan ini menuntut pengakuan eksistensi sekaligus penghormatan timbal balik, dengan catatan penghormatan dimaksud bukan berarti menerima pendapat, agama atau keyakinan pihak lain, melainkan menerima eksistensi mereka untuk hidup berdampingan dalam suasana aman dan damai.

Salah satu yang amat jelas dari kandungan ayat-ayat al-Qur'an adalah larangan melakukan pemaksaan dalam urusan agama. ${ }^{8}$

\footnotetext{
7 M.Quraish Shihab, Wasathiyyah. Wawasan Islam Tentang Moderasi Beragama. Tanggerang, Penerbit Lentera Hati, 2019. Hal 76

${ }^{8}$ M. Quraih Shihab, Islam Yang Disalahpahami. Menepis Prasangka, Mengikis Kekeliruan, Penerbit Lentera Hati, 2018. Hal.109
} 
Biasanya yang paling berharga bagi sesuatu adalah dirinya sendiri. Ini berarti yang paling berharga buat agama adalah agama itu sendiri. Karenanya setiap agama menuntut pengrobanan apapun dari pemeluknya demi mempertahankan kelestariannya. Namun demikian, Islam datang tidak hanya bertujuan mempertahankan eksisensinya sebagai agama, tetapi juga mengakui ekistensi agamaagama lain, dan memberinya hak untuk hidup berdampingan sambil menghormati pemeluk agama lain. ${ }^{9}$

Dalam konteks starta sosial, wasathiyyah (moderasi; mediator; wasit) Islam tampil antara pandangan tentang kebebasan mutlak yang melahirkan perbedaan yang menonjol antara lapisan-lapisan masyarakat dan pandangan yang memandang manusia sama rata sama rasa dengan mengabaikan kenyataan yang terjadi setiap masyarakat manusia. Wasathiyah menekankan adanya perbedaan itu dalam berbagai aspek kehidupan, tetapi ketika mengakui keberadaan aneka peringkat, ditekankannya bahwa itu bertujuan "agar manusia dapat saling memanfaatkan (Q.S Az-Zukruf [43:32) dan dapat hidup berdampingan dan bantu-membantu untuk saling melengkapi, lalu masing-masing memperoleh sesuai kadar mereka yang berbedabeda itu, baik dalam kemampuan maupun kebutuhannya.

Selanjutnya, karena dalam satu masyarakat terdapat berbagai agama dan kepercayaan, maka demi melanggengkan hubungan timbal balik yang harmonis itu aneka petunjuk baik perintah maupun larangan ditegaskan Allah s.w.t antara lain dalam firman-Nya:

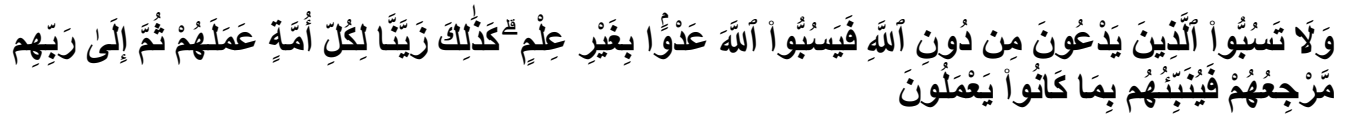

Janganlah kamu memaki sesembahan-sesembahan yang mereka sembah selain Allah, maka (akibatnya) mereka akan memaki Allah dengan melampaui batas tanpa pengetahuan. Demikianlah Kami perindah bagi setiap umat amal mereka. Kemudian kepada Tuhan merekalah kembali mereka, lalu Dia memberitakan kepada mereka apa yang dahulu mereka kerjakan (Q.S. Al-An'am [6]:108).

Allah melarang penghinaan itu, walau sang muslim menganggap buruk apa yang mereka lakukan, karena setiap kelompok masyarakat memiliki pandangan dan aktivitas yang diangaapnya baik. Pilihan mereka harus dihormati-setuju atau tidak, suka atau tidak.

Dalam Q.S Al-Hajj (22):39-40, Allah menegaskan bahwa Dia Yang Mahakuasa itu mengizinkan bagi mereka yang teraniaya untuk berperang dalam rangka membela diri karena:

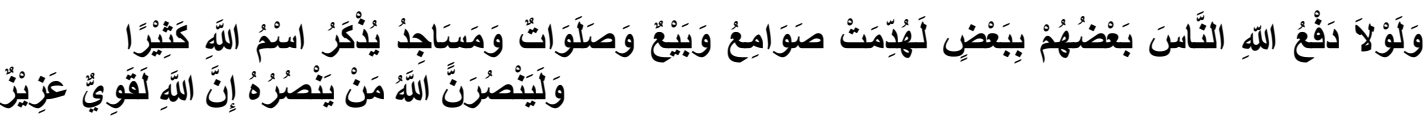

${ }^{9}$ M. Quraish Shihab, Wawasan Al-Quran, Tafsir Tematik atas Pelbagai Persoalan Ummat, Bandung, PT Mizan Pustaka, Hal. 498 
Sekiranya Allah tidak menolak (keganasan) sebagian manusia dengan (mengizinkan pembelaan) sebagian manusia yang lain, tentulah telah dirobohkan oleh para penindas biara-biara Nasrani, dan gereja-gereja, serta sinagoge-sinagoge (tempat-tempat peribadatan orang Yahudi) dan masjid-masjid, yang merupakan tempat-tempat yang di dalamnya banyak disebut nama Allah. Allah pasti memenangkan siapa yang membela-Nya (membela kaum tertindas itu). Sesungguhnya Allah Mahakuat lagi Mahaperkasa.

Tetapi, Allah tidak menghendaki dirobohkannya tempa-tempat peribadatan itu sehingga Dia mengizinkan pembelaan itu. ${ }^{10}$

Dalam berinteraksi sosial dengan nonmuslim, ajaran wasathiyyah memberi kesempatan kepada siapa pun untuk agama dan kepercayaannya (Q.S. Al-Kafirun [109:1-9), bahkan menganjurkan kerjasama dengan siapapun dalam kebajikan dan ketakwaan. Sebaliknya, tidak menerima kerja sama walau dari yang mengaku muslim jika ajakan itu mengantar pada kedurhakaan dan dosa (Q.S Al-Maidah [5]: 2).

\section{Rujukan Toleransi dalam Al-Qur'an}

Sebelum membahas arti toleransi dalam Islam, perlu ditelusuri terlabih dahulu ayat-ayat Al-Qur'an yang menjadi sumber rujukan dalam pegembangan, baik perspektif konseptual maupun aplikasinya dalam kehidupan keberagamaan. Tidak diragukan lagi bahwa, toleransi dianjurkan oleh Islam baik secara historical eksplisit maupun implisit. Jauh dari sekedar wacana, sejak awal Islam telah mencanangkan adanya perbedaan dan dengan jelas menyatakan bahwa perbedaan adalah sunnatullah, yang mengukuhkan sebagai ketetapan dan kehendak Tuhan, bukan keinginan manusia. Di antara ayat-ayat Al-Qur'an yang mengacu pada eksistensi perbedaan, kesemuanya memberikan sinyal dan arahan kepada ummat manusia sebagai individu maupun kelompok bahwa apabila kenyataan berbeda, perbedaan yang alami dan bersifat turun temurun, maka perbedaan itu harus diterima. ${ }^{11}$

Ajaran akan kemajemukkan keagamaan itu menandaskan pengertian dasar bahwa semua agama diberi kebebasan untuk hidup, dengan resiko yang ditanggung oleh para pengikut agama itu masing-masing, baik secara pribadi maupun secara kelompok. Sikap demikian ditafsirkan sebagai suatu harapan kepada semua agama yang ada. Karena semua agama itu pada mulanya menganut prinsip yang sama, yaitu keharusan manusia untuk berserah diri kepada Yang Maha Esa, maka agama-agama itu, baik karena dinamika internalnya atau karena persinggungannya satu sama lain, secara berangsur-angsur akan menemukan kebenaran asalnya sendiri, sehingga semuanya akan bertumpu dalam suatu "titik pertemuan", "common platform" atau

10 M.Quraish Shihab, Wasathiyyah. Wawasan Islam Tentang Moderasi Beragama. Tanggerang, Penerbit Lentera Hati, 2019. Hal. 80

${ }^{11}$ Alwi Shihab, Islam dan Kebinakaan, Jakarta: PT Gramedia Pustaka Uatama, 2019. Hal. 4 
dalam istilah al-Qur'an, "Kalimah sawa",, 12 sebagaimana hal itu diisyaratkan dalam sebuah perintah Allah kepada Rasul-Nya Nabi Muhammad s.a.w:

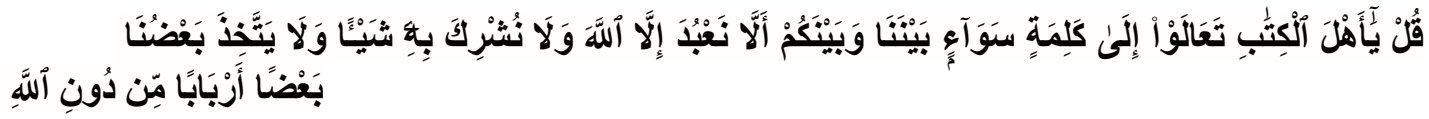

Katakanlah olehmu Muhammad :'Wahai Ahli Kitab! Marilah menuju ke titik pertemuan (kalimah sawa') antara kami dan kamu; yaitu bahwa kita tidak menyembah selain Allah dan tidak pula memperserikatkan-Nya kepada apapun, dan bahwa sebagian dari kita tidak mengangkat sebagian yang lain sebagai 'tuhantuhan' selain Allah."...

Melalui diksi sunnatullah tersebut, Al-Qur'an memberikan tuntunan yang dalam implementasinya membuktikan bahwa semakin banyak individu maupun kelompok dapat menerima perbedaan dan menyikapinya dengan kecerdasan, menunjukkan semakin luas zona jangkauan pengembangan (width) dan semakin dalam zona integritas religinya (depth) dalam membangun peradaban kemanusiaan. Melalui diksi tersebut pula, manusia dibimbing untuk mengelola perbedaan, mengelola tidak hanya untuk relasi antar manusia secara horizontal melainkan juga relasi vertical sebagai bentuk ketaatan dan ketakwaan manusia pada amanat penciptaannya. Pada titik ini toleransi menjadi indikator perilaku yang Islami. ${ }^{13}$

Sekian banyak teks Al-Qur'an dan Hadis yang menuntun manusia untuk memelihara toleransi dan kebersamaan.

Inti nilai keagamaan adalah interaksi positif, demikian bunyi teks hadis Nabi saw “ad-Dien al Mu'amalah”. Tidak sebatas hanya interaksi positif vertical dan horizontal dengan Tuhan dan manusia, tetapi mencakup pula interaksi dengan alam semesta, hewan, dan lingkungan. Demikian pula dengan semangat yang sama perintah Tuhan untuk menjaga kebersamaan dengan sesama manusia yang diciptakan beraneka ragam bangsa dan golongan.

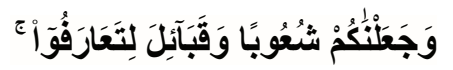

Art'inya: "Dan Kami (Allah) jadikan kalian bersuku-suku dan berbangsa-bangsa agar kalian saling mengenal.” (Qs.Al-Hujurat [49]:13)

Karena prinsip ajaran Nabi dan Rasul itu sama, maka para penganut semua nabi dan rasul adalah ummat yang satu. Dengan kata lain, konsep kesatuan dasar ajaran membawa kepada konsep kesatuan kenabian dan kerasulan, yang kemudian, dalam urutannya sendiri, membawa kepada konsep kesatuan umat yang beriman, ini di tegaskan dalam firman Ilahi:

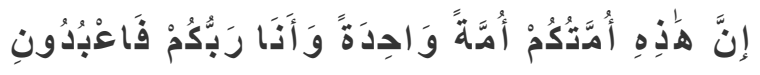

\footnotetext{
${ }^{12}$ Nurcholis Madjid, Islam Doktrin dan Peradaban, Jakarta Selatan: PARAMADINA, 2015. Hal. 180181

${ }^{13}$ Alwi Shihab, Islam dan Kebinakaan, Jakarta: PT Gramedia Pustaka Uatama, 2019. Hal. 5
} 
Sesungguhnya ini adalah ummatmu semua (wahai para rasul), yaitu ummat yang tunggal, dan aku adalah Tuhanmu, maka sembahlah olehmu sekalian akan Daku (saja). (al-Anbiya 21;92).

\section{Kerukunan dan Demokrasi}

Biasanya yang paling berharga bagi sesuatu adalah dirinya sendiri. Ini berarti yang paling berharga buat agama adalah agama itu sendiri. Karenanya setiap agama menuntut pengorbanan apapun dari pemeluknya demi mempertahankan kelestariannya. Namun demikian, Islam datang tidak hanya bertujuan mempertahankan eksistensinya sebagai agama, tetapi juga mengakui eksistensi agama-agama lain, dan memberinya hak untuk hidup berdampingan sambil menghormati pemeluk-pemeluk agama lain.

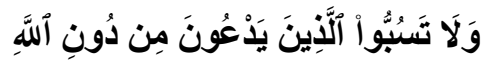

Jangan mencerca yang tidak menyembah Allah (penganut agama lain)... (QS Al-An'am [6]:108.

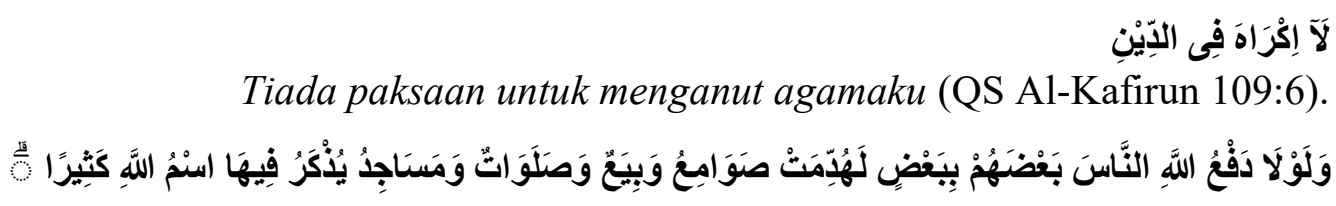

Artinya:

Seandainya Allah tidak menolak keganasan sebagian orang atas sebagian yang lain (tidak mendorong kerja sama antara manusia), niscaya robohlah biarabiara, gereja-gereja, rumah-rumah ibadah orang Yahudi dan masjid-majid, yang di dalamnya banyak disebut nama Allah. ${ }^{14}$

Ayat ini dijadikan oleh sebagian ulama, seperti Al-Qurthubi (w.671 H), sebagai argumentasi keharusan ummat Islam memelihara tempat-tempat ibadah umat non-Muslim. Memang, Al-Quran sendiri amat tegas menyatakan bahwa,

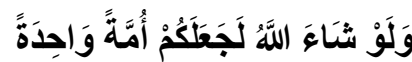

Seandainya Allah menghendaki, niscaya Dia menjadikan seluruh manusia menjadi satu umat saja (QS Al-Nahl [16]:93).

14 Akan tetapi Allah tidak menghendaki dirobohkannya tempat-tempat peribadatan itu sehingga Dia mengizinkan pembelaan itu. Dalam berinteraksi sosial dengan non muslim, ajaran wasathiyyah memberi kesempatan kepada siapa pun untuk melaksanakan agama dan kepercayaannya (QS. Al-Kafirun [109]: 1-9). Dalam wasathiyyah Wawasan Islam Tentang Moderasi Beragama. Hal.80 
Tetapi Allah tidak menghendaki yang demikian, karena itu Dia memberikan kebebasan kepada manusia untuk memilih sendiri jalan yang dianggapnya baik, mengemukakkan pendapatnya secara jelas dan betanggung jawab. Di sini dapat ditarik kesimpulan bahwa kebebassan berpendapat, termasuk kebebasan memilih agama, adalah hak yang dianugerahkan Tuhan kepada setiap insan.

Yang dikemukakan ayat Al-Qur'an tersebut merupakan salah satu benih dari ajaran demokrasi, hal mana kemudian akan tampak jelas dalam petuntukpetunjuk Kitab Suci. Salah satu yang dapat dikemukakan disini adalah pengalaman Nabi Muhammad Saw. dalam peperangan Uhud serta kaitannya dengan ayat memerintahkan musyawarah. Sejarah menginformasikan bahwa ketika mendengar berita rencana serangan musuh-musuh Nabi Saw dari Makkah ke Madinah, Nabi saw. berpendapat bahwa lebih baik menunggu mereka hingga sampai ke kota Madinah. Namun, mayoritas sahabat-sahabatnya dengan penuh semangat mendesak beliau agar menghadapi mereka di luar kota, yakni di Uhud. Karena desakan itu, akhirnya Nabi menyetujui. Akan tetapi ternyata puluhan sahabat Nabi gugur dalam peperangan tersebut sehingga menimbulkan penyesalan. Setelah pengalaman pahit mengikuti pendapat mayoritas ini, justru Al-Qur'an turun memberi petunjuk kepada Nabi Muhammad Saw, agar tetap melakukan musyawarah dan selalu bertukar pikiran dengan sahabat-sahabatnya. ${ }^{15}$

Demikian terlihat kebebasan beragama, mengemukakan pendapat, dan demokrasi merupakan prinsip-prinsip ajaran Islam.

Atas dasar itu pula, kitab suci umat Islam mengakui kenyataan tentang banyaknya jalan dapat ditempuh ummat manusia. Mereka diperintahkan untuk berlomba-lomba dalam kebajikan (QS AL-Baqarah [2]:148), kesemuanya demi kedamaian dan kerukunan:

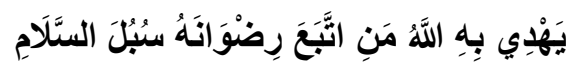

Allah memberi petunjuk melalui wahyu-Nya yang keridhaan-Nya dengan menelusuri jalan-jalan kedamaian (QS Al-Maidah [5]:16).

Sekali lagi ditemukan bahwa kebhinekaan diakui atau ditampung selama bercirikan kedamaian. Bahkan dalam rangka mewujudkan kedamaian dengan pihak lain, Islam menganjurkan dialog yang baik (QS AL-Nahl [16:125). Dan dalam dialog itu, seorang Muslim tidak dianjurkan untuk mengklaim kepada mitra dialognya bahwa kebenaran hanya menjadi miliknya.

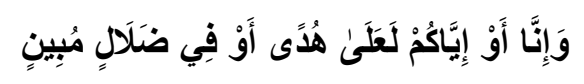

\footnotetext{
${ }^{15}$ M. Quraish Shihab, Wawasan Al-Quran; Tafsir Tematik atas Pelbagai Persoalan Ummat. Bandung. PT Mizan Pustaka, 2007. Hal.501
} 
Katakanlah, Kami atau Anda yang berada dalam kebenaran atau kesesatan yang nyata (Q.S Saba' [34]:24).

Bahkan lebih jauh dari itu kitab suci ummat Islam mengajarkan agar setiap muslim hendaknya tidak melontarkan kata atau kalimat-kalimat dialog yang pada lahirnya dapat dinilai “merugikan”. Perhatikan terjemahan ayat berikut:

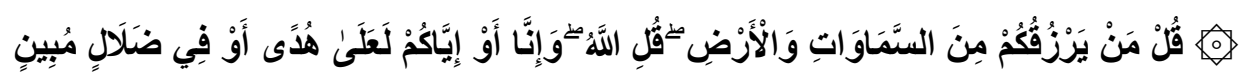

Kamu sekalian tidak akan diminta untuk mempertanggungjawabkan dosadosa kami. Kamipun tidak akan mempertanggungjawabkan perbuatan-perbuatan kalian. (QS Saba' [34]:25).

Kita menamai perbuatan kita dosa, dan tidak menampakkan perbuatan mitra dialog non-Muslim sebagai dosa, tetapi menyebutnya sebagai "perbuatan".

\section{Sikap dan Perilaku Toleran}

Indonesia diberikan karunia luar biasa. Indonesia adalah surga yang sangat cantik dan kekayaannya melimpah, namun juga karakter keberagamannya begitu soft, menempatan agama dan Negara dalam keragaman. Tak dapat dipungkiri bahwa Indonesia adalah rujukan idel hubungan Islam dan demokrasi.

Pengakuan dunia akan indahnya toleransi di Indonesia bukanlah isapan jempol. Hari ini Negara-negara Islam di Timur Tengah dan beberapa Negara yang tengah dilanda konflik, sangat respek terhadap sikap Indonesia yang netral dalam konflik yang ada di antara dunia Islam. Indonesia bukan diterima dengan baik oleh Negara-negara yang saling berkonflik. Ini menunjukkan bahwa muslim Indonesia adalah referensi besar tentang moderasi dan toleransi.

Kondisi ini tentu bukan hanya membanggakan bangsa Indonesia. Namun juga sebagai tantangan besar mengingat menjaga toleransi bukanlah hal mudah, apalagi jika dihadapkan pada fenomena beberapa paham belakangan ini yang semakin agresif berpenetrasi kedalam system sosial kemasyarakatan. Tantangan kita saat ini adalah bagaimana memperkuat toleransi sebagai fondasi hidup berbangsa dan bernegara.

Dalam konteks kehidupan berbangsa dan bernegara, toleransi diwujudkan melalui perilaku yang mengedepankan persatuan dan perdamaian. Toleransi mendorong setiap perbedaan diselesaikan dengan cara damai dan berorientasi pada solusi yang dapat diterima bersama. Karena itulah wujud toleransi dapat dilihat dari beberapa sikap yakni, tidak mengusik kerukunan, tidak merusak dan menganggu 
Rumah Ibadah, menghindari nomenklatur sensitive dan menghormati tokoh agama lain. ${ }^{16}$

Toleransi (Latin: tolerale) berarti mengendalikan diri, bersabar, memberi kesempatan orang berpendapat lain dan lapang dada menerima perbedaan. Dalam kamus Bahasa Indonesia toleransi diartikan sebagai sikap menghargai, membiarkan, membolehkan pendirian (pendapat, pandangan kepercayaan) yang berbeda atau bertentangan dengan pendirian sendiri.

Toleransi tidak mesti diartikan membenarkan pendapat yang berbeda tetapi mengakui hak asasi orang lain untuk berpendapat. Sikap toleransi mengimplisitkan adanya pengakuan terhadap pluralitas dan kebhinekaan antara sesama warga masyarakat tanpa membedakan jenis kelamin, etnis, agama, dan kepercayaan. Toleransi tidak identik dengan pembenaran nilai-nilai yang dianut orang lain. Perbedaan pandangan tetap ada tetapi perbedaan itu tidak perlu melahirkan pertentangan, apalagi permusuhan satu sama lain.

Toleransi antar umat beragama artinya pengakuan, bukan pembenaran, terhadap agama-agama orang lain. Biarkanlah orangorang lain menjalankan agamanya masing-masing, sementara kita tetap menjalankan agama kita, tanpa saling mengusik eksistensi ajaran agama orang lain. Sangat indah redaksi yang

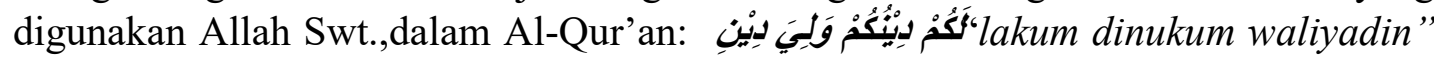
(Untukmu agamamu dan untukku agamaku). Mungkin tidak ada kitab suci seterbuka Al-Qur'an dalam mengungkap pentingnya sikap toleransi. Puluhan kali Al-Qur'an menyebutkan eksistensi agama-agama lain secara eksplisit seperti Yahudi, nasrani, dan Majusi.

Dalam tradisi Islam, toleransi diistilahkan dengan tasamuh, dari kata samuha-yasmahu berarti murah hati, memaafkan. Tasamuh sering dihubungkan atau mempunyai kemiripan arti dengan ihtimal (akomodatif), tasahul (lapang dada) dan samhah atau samahah (kemurahan dan kelapangan dada). Nuansa kebatinan tasamuh lebih terasa teduh dan damai daripada tolerance yang mengimplikasikan adanya unsur keterpaksaan atau tekanan dari luar.

Toleransi atau tasamuh lebih terasa dan terlihat makanya dalam masyarakat plural dan heterogen seperti di Indonesia yang terdiri atas bebagai etnis, agama, adatistiadat, dan kearifan lokal. Semakin plural dan heterogen suatu bangsa atau komunitas semakin perlu sikap toleransi. Masyarakat plural-heterogen tanpa sikpa toleransi. Masyarakat plural-heterogen tanpa sikap toleran atau tasamuh pasti selalu diwarnai oleh ketegangan primodial dan konseptual.

Sebagai bangsa yang besar, amat plural dan heterogen, Indonesia mutlak memerlukan perawatan sikap toleransi. Jika toleransi terusik maka ancaman disintegrasi bangsa akan terancam. Prinsip Bhineka Tunggal Ika harus mendarah

\footnotetext{
${ }^{16}$ Nasaruddin Umar, Islam Nusantara “Jalan Panjang Moderasi Beragama Di Indonesia”, Jakarta: PT Elex Media Komputindo, 2019.Hal.229
} 
daging bagi segenap warga bangsa Indonesia jika mereka menghendaki negerinya hebat. Nasionalisme Indonesia sudah teruji keampuhannya dalam merawat dan melindungi NKRI. Sudah beberapa kali NKRI diramal oleh para futurology asing akan hancur berkeping-keping lalu jatuh ke dalam genggaman Negara-negara adidaya, tetapi sekali lagi, berkat rahmat Allah Swt.,,ramalan-ramalan itu masih terus meleset. ${ }^{17}$

Senua jalan yang terbentang mengantar kepada kerugian dan kecelakaan, kecuali jalan yang bercirikan kedamaian. Bersikap damai mengundang pemberian yang baik dan sesuai, atau paling sedikit, bila tidak memberi manfaat, maka tidak mencelakakkan atau mengambil hak siapapun. Karena itu, kalau anda tak dapat menggembirakan, maka jangan meresahkan; kalau tak dapat memuji, maka jangan mencela. Terhadap yang berbuat jahil pun al-Qur'an menganjurkan agar diberikan kepadanya kedamaian pasif. "Hamba Allah Yang Maha Rahman adalah mereka yang berjalan di bumi tanpa angkuh dan bila disapa oleh yang picik, ia berkata salam," yakni mari berpisah dalam kedamaian (QS. Al-Furqan [25]:63). ${ }^{18}$

Perdamaian dan kerukunan yang didambakkan Islam, bukanlah bersifat semu, tetapi yang memberi rasa aman pada jiwa setiap insan. Karena itu, langkah pertama yang dilakukannya adalah mewujudkannya dalam jiwa setiap pribadi. Setelah itu, ia melangkah kepada unit terkecil dalam masyarakat yakni keluarga. Dari sini ia beralih ke masyarakat luas, seterusnya kepada seluruh bangsa di permukaan bumi ini, dan dengan demikian dapat tercipta perdamaian dunia, dan dapat terwujud hubungan harmonis serta toleransi dengan semua pihak.

Perlu dicatat bahwa Allah tidak menegaskan bahwa manusia merupakan sebaik-baik makhluk-Nya, akan tetapi yang Dia tegaskan adalah "Dia memuliakan manusia dan Dia menganugerahinya aneka kelebihan atas banyak makhlukmakhluk-Nya yang lain (QS. Al-Isra' 17:70). Dinyatakan pula bahwa Allah telah menciptakan manusia dalam bentuk fisik dan psikis yang terbaik (QS at-Tin 95:4).

Seluruh manusia dalam pandangan Islam memiliki kedudukan yang sama dari segi kemanusiaan, meskipun berbeda suku, agama, warna kulit, jenis kelamin dan sebagainya. Semua telah Allah muliakan. Kehormatan manusia harus dipelihara baik saat dia hidup maupun setelah kematiannya karena dia adalah manusia.

Hal demikian pernah dicontohkan oleh sang role of model baginda Nabi Muhammad saw, ketika ada jenazah yang di usung melintas di hadapan Nabi Muhammad saw., beliau berdiri menghormatinya. Salah seorang menyampaikan kepada beliau saw bahwa itu adalah jenazah non muslim. Sentak beliau berkomentar: "Bukankah dia juga manusia?" demikian juga sikap beliau saw terhadap musuhmusuh beliau yang tewas dalam perang badar yang ketika itu berkelimpangan di

\footnotetext{
${ }^{17}$ Ibid. Hal. 197

${ }^{18}$ M. Quraish Shihab. Mutiara Hati. Mengenal Iman, Islam, dan Ihsan Bersama M. Quraish Shihab, Tanggerang. Penerbit Lentera Hati, 2014 Hal. 35
} 
medan perang. Beliau saw memerintahkan agar yang tewas itu dikubur secara wajar. Karena betapapun mereka juga manusia, sementara pakar berkata bahwa manusia lebih mulia dari K'abah yang merupakan arah kiblat shalat kaum muslimin dan lambang "rumah Tuhan". Kakbah itu ciptaan manusia, sedang manusia ciptaan Allah. Demikian kurang lebih apa yang di sampaikan oleh pakar tafsir kenamaan Prof. Dr. M. Quraish Shihab, M.A dalam bukunya yang berjudul Islam Yang Saya Anut "Dasar-dasar Ajaran Islam". 19

Pada akhirnya kita dapat berkata bahwa, seluruh manusia dalam pandangan Islam, memiliki kedudukan yang sama dari segi kemanusiaan, meskipun berbeda suku, bangsa, agama, warna kulit, jenis kelamin dan sebagainya. Semua telah Allah swt muliakan kehormatan manusia harus dipelihara baik saat dia hidup maupun setelah kematiannya karena dia adalah manusia.

\section{KESIMPULAN}

Banyak jalan menuju ke Roma, begitu kata orang. Banyak juga jalan menuju ke surga, begitu pesan agamawan. Allah menamainya Subul as-Salam, yani jalanjalan kedamaian (QS. Al-Ma'idah [5]:16). Jalan apapun yang tidak bercirikan kedamaian, maka pejalanannya dalam bahaya. Sungguh lebih baik berhenti di persimpangan jalan ketimbang menelusuri jalan yang sesat, karena kesesatan bila berlanjut semakin menjauhkan dari arah yang benar. Di sisi lain, beraneka ragamnya jalan, mengundang setiap pejalan berwawasan luas dan toleran terhadap pejalan lain. Sekali lagi, jalan menuju ke surga banyak, lebar, dan lurus. Para pejalan tidak perlu berdesakan, apalagi bertengkar dan saling menyalahkan.

Dalam implementasi nilai-nilai pendidikan maka perlu menumbuhkan sikap toleran. Hal demikian dapat dilakukan dengan penyadaran pandangan bahwa manusia di sisi Allah karena sama-sama makhluk Allah (QS.17:70). Perbedaan paham, pandangan hidup, agama, dan sebagainya. Allah-lah yang akan menyelesaikannya, dan itu terjadi di akhirat (QS.16:125, QS.22:17). Yang perlu diselesaikan di dunia, oleh manusia, ialah masalah pelanggaran hukum. ${ }^{20}$

Kontribusi penelitian ini bagi pendidikan yakni, pendidikan harus menumbuhkan rasa cinta, respek, dan hormat-menghormati antara sesama manusia. Pada calon pemimpin, sifat itu harus mendalam dan merupakan sifat dasarnya. Pendidikan juga perlu berhasil dalam menumbuhkan sifat pemaaf, patuh pada aturan (disiplin), dan musyawarah (demokratis). Hasil musyawarah harus dilaksanakan dengan konsekuen, penerapan hukum haruslah tanpa pandang bulu. Adapun dalam implementasi nilai-nilai pendidikan, maka pendidikan demokratis dapat didekati

${ }^{19}$ M. Quraish Shihab. Islam yang Saya Anut, Dasar-dasar Ajaran Islam, Tanggerang: Penerbit Lentera Hati, 2018), Hal. 67

${ }^{20}$ Salman Harun, Tafsir Tarbawi, Nilai-nilai Pendidikan dalam Al-Quran, Tanggerang Selatan: Penerbit Lentera Hati. 2019. Hal. 63 
dengan menumbuhkan kesadaran bahwa manusia itu sama dalam pandangan Allah dan punya hak-hak asasi. Metodenya berupa ceramah, cerita, kerja kelompok, teladan, dan sebagainya.

\section{E. DAFTAR PUSTAKA}

Alwi Shihab. 2019. Islam dan Kebinakaan, Jakarta: PT Gramedia Pustaka Utama.

M. Quraish Shihab. 2019. Wasathiyyah. Wawasan Islam Tentang Moderasi Beragama. Tanggerang, Penerbit Lentera Hati.

M. Quraish Shihab. 2018. Islam Yang Disalahpahami. Menepis Prasangka, Mengikis Kekeliruan, Penerbit Lentera Hati.

M. Quraish Shihab. 2018. Islam yang Saya Anut, Dasar-dasar Ajaran Islam, Tanggerang: Penerbit Lentera Hati.

M. Quraish Shihab. 2014. Mutiara Hati. Mengenal Iman, Islam, dan Ihsan Bersama M. Quraish Shihab, Tanggerang. Penerbit Lentera Hati.

M. Quraish Shihab. 2007. Wawasan Al-Quran; Tafsir Tematik atas Pelbagai Persoalan Ummat. Bandung. PT Mizan Pustaka.

Musa Asy’Arie. 2002. Filsafat Islam, Sunnah Nabi Dalam Berpikir, Yogyakarta: LESFI.

Nasaruddin Umar, 2019. Islam Nusantara "Jalan Panjang Moderasi Beragama Di Indonesia”, Jakarta: PT Elex Media Komputindo.

Nurcholis Madjid, 2015. Islam Doktrin dan Peradaban, Jakarta Selatan: PARAMADINA.

Ronny Kountur, 2005. Metode Penelitian untuk Penulisan Skripsi dan Tesis. Jakarta: PPM.

Salman Harun, 2019. Tafsir Tarbawi, Nilai-nilai Pendidikan dalam Al-Quran, Tanggerang Selatan: Penerbit Lentera Hati.

Sutrisno Hadi, 1990. Metodologi Research, Yogyakarta: Andi Ofset. 